\title{
INTRODUKSI INCUBATOR BUATAN UNTUK MEMPERSINGKAT WAKTU PEMBUATAN DADIH
}

\author{
Khairul Amri ${ }^{(1)}$,Aronald Arif Putra ${ }^{(2)}$
}

(1) Jurusan Teknik Mesin, Politeknik Negeri Padang (2) Faterna Universitas Andalas

\begin{abstract}
ABSTRAK
Dadih merupakan produk makanan fermentasi khas Sumatera Barat yang diproduksi dengan cara menyimpan susu kerbau di dalam tabung bambu dan membiarkannya selama 2-3 hari sehingga terjadi proses fermentasi yang dilakukan bakteri asam laktat yang berasal dari tabung bambu atau daun pisang atau dari susu itu sendiri, sehingga menghasilkan tekstur yang padat dan mempunyai rasa asam yang spesifik serta memiliki sifat fisikokimia yang sama dengan susu fermentasi seperti yogurt. Tujuan dari penelitian yang dilakukan adalah perancangan dan pembuatan alat incubator untuk mempersingkat waktu pembuatan dadih. Metoda kerja incubator adalah dilengkapi alat control temperature beserta pewaktu dimana suhu ruang incubator akan dijaga konstan pada range suhu optimal yang dibutuhkan oleh bakteri asam laktat untuk berkembang. Disisi lain, pewaktu digunakan sebagai pengingat dan pemberi informasi bagi petani Dadiah bahwa dadiah yang dibuat terlah terbentuk dengan sempurna. Dari hasil pengujian daidapat control temperature dan pewaktu yang dibuat pada alat incubator dadiah dapat bekerja dengan baik dan sesuai dengan alat ukur standar; stopwatch untuk waktu dan thermometer digital untuk temperature. Sesuai dengan teori yang dijelaskan oleh Lee and Lucey, (2010) bahwa bakteri asam laktat berkembang dengan cepat pada suhu $40{ }^{\circ} \mathrm{C}$, ini terlihat dari proses pembuatan dadiah yang hanya butuh waktu 5 jam, dibandingkan dengan proses tradisional yang memerlukan waktu selama 50 jam.
\end{abstract}

Keyword: incubator buatan, dadiah, permentasi

\section{Pendahuluan}

Dadih merupakan produk makanan fermentasi khas Sumatera Barat yang diproduksi dengan cara menyimpan susu kerbau di dalam tabung bambu dan membiarkannya selama 2-3 hari sehingga terjadi proses fermentasi yang dilakukan bakteri asam laktat yang berasal dari tabung bambu atau daun pisang atau dari susu itu sendiri, sehingga menghasilkan tekstur yang padat dan mempunyai rasa asam yang spesifik serta memiliki sifat fisikokimia yang sama dengan susu fermentasi seperti yogurt dari Timur Tengah dan dahi dari India. Banyak produk turunan yang bisa dihasilkan dari dadiah diantaranya; jelly, minuman segar atau penambah rasa maupun penambah aroma makanan dan minuman, dan sebagai isian roti (Murwani; 2006). Banyaknya difersifikasi produk turunan dari dadiah ini mampu meningkatkan jumlah peminat dadiah dari waktu ke waktu.

Dari literatur yang ada menyebutkan bahwa genus bakteri asam laktat yang dapat dijumpai pada dadih diantaranya : Streptococcus, Lactobalcillus, dan Leuconostoc (Sugitha dan Afriyani, 2004) yang sebenarnya juga bisa dijumpai pada beberapa produk fermentasi lain dengan berbagai species bakteri asam laktatnya. Pada prakteknya, proses pembuatan dadih secara tradisional adalah masih memanfaatkan kondisi lingkungan melalui penyimpanan pada temperatur ruang $\left( \pm 27^{\circ} \mathrm{C}\right)$. Padahal sebenarnya, bakteri asam laktat terutama yang bersifat thermophilic yang sebagian besar ada pada kebanyakan susu fermentasi memiliki temperatur pertumbuhan optimal pada suhu sekitar $40-45^{\circ} \mathrm{C}$ (Lee and Lucey, 2010), walaupun 
pada temperatur ruang sebenarnya tetap bisa bermetabolisme. Akibatnya, diperlukan waktu yang cukup panjang dimana secara umum produksi dadih dari awal pembuatan menghabiskan masa sekitar 2 hingga 3 hari sampai susu kerbau yang dimasukkan ke dalam tabung mampu mengalami proses fermentasi sempurna menghasilkan dadih. Untuk mengatasi lamanya waktu produksi dadiah maka akan diperkenalkan metoda baru yaitu dengan membuat incubator yang dilengkapi alat control temperature beserta pewaktu. Suhu ruang incubator akan dijaga konstan pada range suhu optimal yang dibutuhkan oleh bakteri asam laktat untuk berkembang. Disisi lain, pewaktu digunakan sebagai pengingat dan pemberi informasi bagi petani Dadiah bahwa dadiah yang dibuat terlah terbentuk dengan sempurna.

\section{Teori Dasar Dadiah}

Berbeda hal nya dengan yogurt yang terbuat dari susu sapi, dadiah dibuat dari susu kerbau yang difermentasikan oleh bakteri yang berasal dari tabung bambu, daun pisang yang digunakan sebagai wadah dan penutup tabung dadiah ataupun yang berasal dari susu kerbau itu sendiri (Azria, 1986, Zakaria et al, 1998). Ilustrasi proses pembuatannya seperti yang terlihat pada Gambar 1.

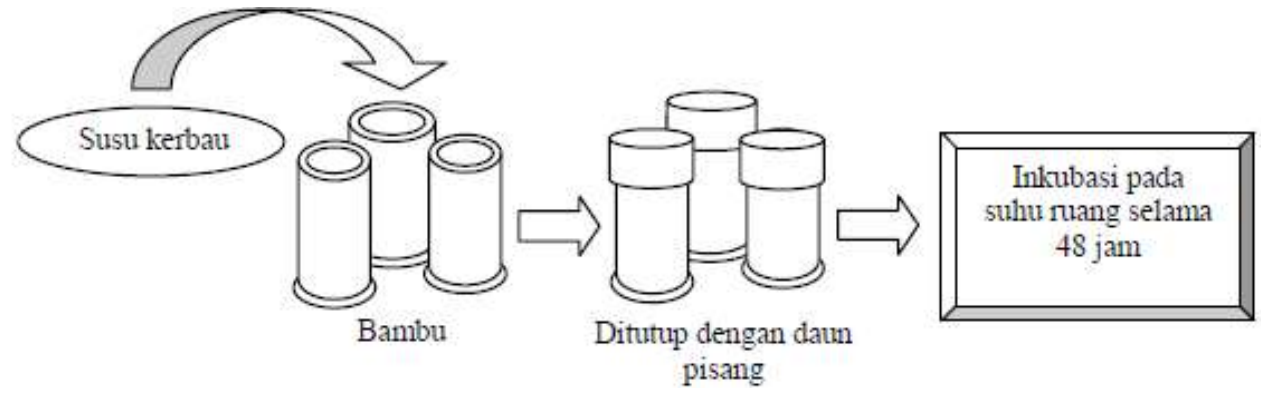

Gambar 1. Proses Pembuatan Dadih Secara Tradisional (Sirait 1993).

Banyak keunggulan yang dimiliki oleh dadiah dibandingkan dengan yogurt antara lain kandungan protein yang hampir 2 kali lipat, namun jumlah lemak yang dikandungnya hampir 5 kali lebih banyak dibandingkan yogurt seperti yang diperlihatkan pada Tabel 1 Kandungan senyawa yang ada pada dadiah dan yogurt (Yudoamijoyo et al; 1983) sebagai berikut:

Tabel 1. Kandungan senyawa yang ada pada dadiah dan yogurt

\begin{tabular}{cccccccc}
\hline & $\mathrm{pH}$ & T.A & Protein & Lemak & Karbohidrat & Abu & Kadar air \\
\hline Yogurt & 3,4 & 1,490 & 3,91 & 0,007 & 4,32 & 0,92 & 90,78 \\
Dadiah A & 4,1 & 1,278 & 5,93 & 5,42 & 3,34 & 0,96 & 84,35 \\
Dadiah B & 4,0 & 1,320 & 7,57 & 6,48 & 3,79 & 1,13 & 81,03 \\
\hline
\end{tabular}

Keterangan : TA = titrable acidity (sebagai asam laktat)

Kadar air $=100 \%$-total bahan kering $(\%)$

A dan B adalah sampel dadih yang berasal dari daerah berbeda 


\section{A. System Control}

System control yang digunakan pada incubator ini menggunakan konsep loop terbuka untuk mengontrol waktu, dan loop tertutup untuk mengontrol temperature. System loop terbuka adalah system control yang outpunya tidak diperhitungkan ulang oleh kontroler. Disisi lain pada system control loop tertutup, output memiliki peranan langsung terhadap sistem pengendalian yang dilakukan sehingga tingkat kestabilan dapat dipertahankan. Diagram blok dari loop terbuka terlihat pada Gambar 2, sedangkan untuk sistem control loop tertutup ada pada Gambar 3.

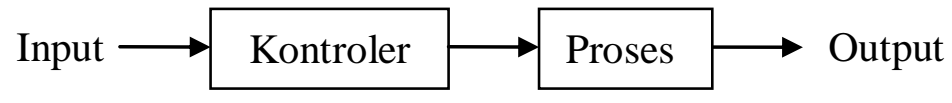

Gambar 2. Sistem control loop terbuka

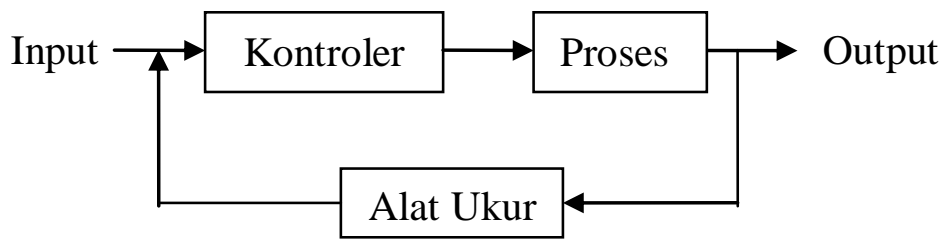

Gambar 3. Sistem control loop tertutup

\section{Sistem perancangan}

Incubator dadiah ini terdiri atas dua komponen utama yaitu sistem hardware dan sitem software. Sistem hardware tersusun atas kotak incubator yang terisolasi dari suhu lingkungan serta rangkain elektronik. Antara ruang pemanas dengan lingkungan luar disekat oleh udara yang berfungsi sebagai isolator sehingga bisa mencegah panas yang ada pada incubator untuk tidak terkonduksi ke lingkungan. Kotak incubator luar terbuat dari triplek yang bersifat isolator yang baik sedangkan ruang incubator sendiri terbuat dari konduktor plat baja $5 \mathrm{~mm}$ yang mampu mendistribusikan suhu dari heater secara merata. Rancangan kotak incubator dapat dilihat pada Gambar 4 berikut:

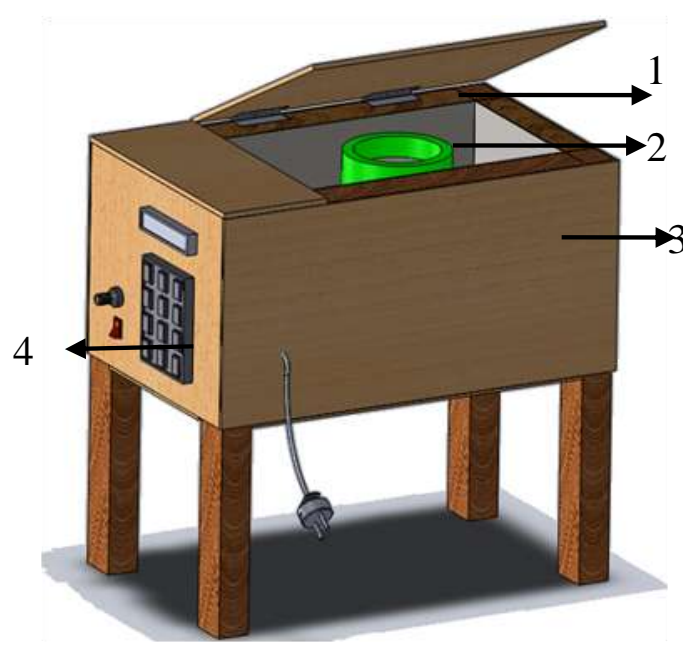

Gambar 4. Rancangan Alat

1. Isolator udara

2. Heater dengan plat baja

3. Triplek

4. Keypad. 
Rancangan instalasi sistem control untuk incubator dadiah diperlihatkan pada gambar 5

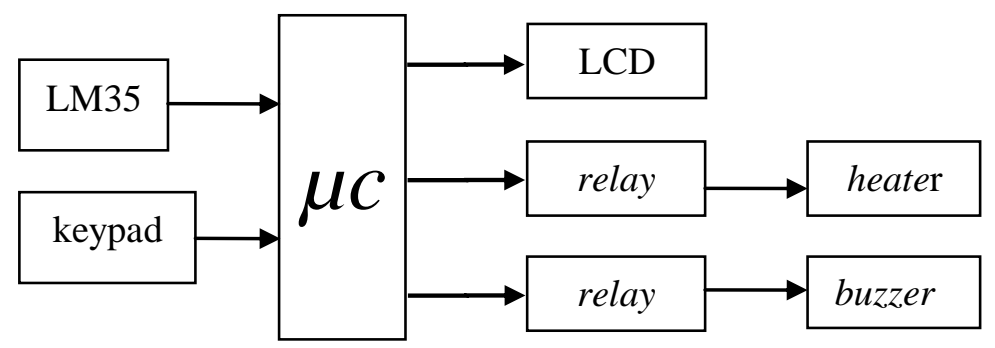

Gambar 5. Blok diagram dari instalasi sistem kontrol

Pada Gambar 5 terlihat input dari sistem kontrol berasal dari dua sumber yaitu LM 35 yang berfungsi sebagai pengindra temperature dan keypad yang digunakan sebagai tempat masukan range temparatur kerja dari incubator serta berapa lamanya (waktu) incubator harus bekerja. Sementara itu, pada sisi output dari mikrokontroller terdapat LCD sebagai

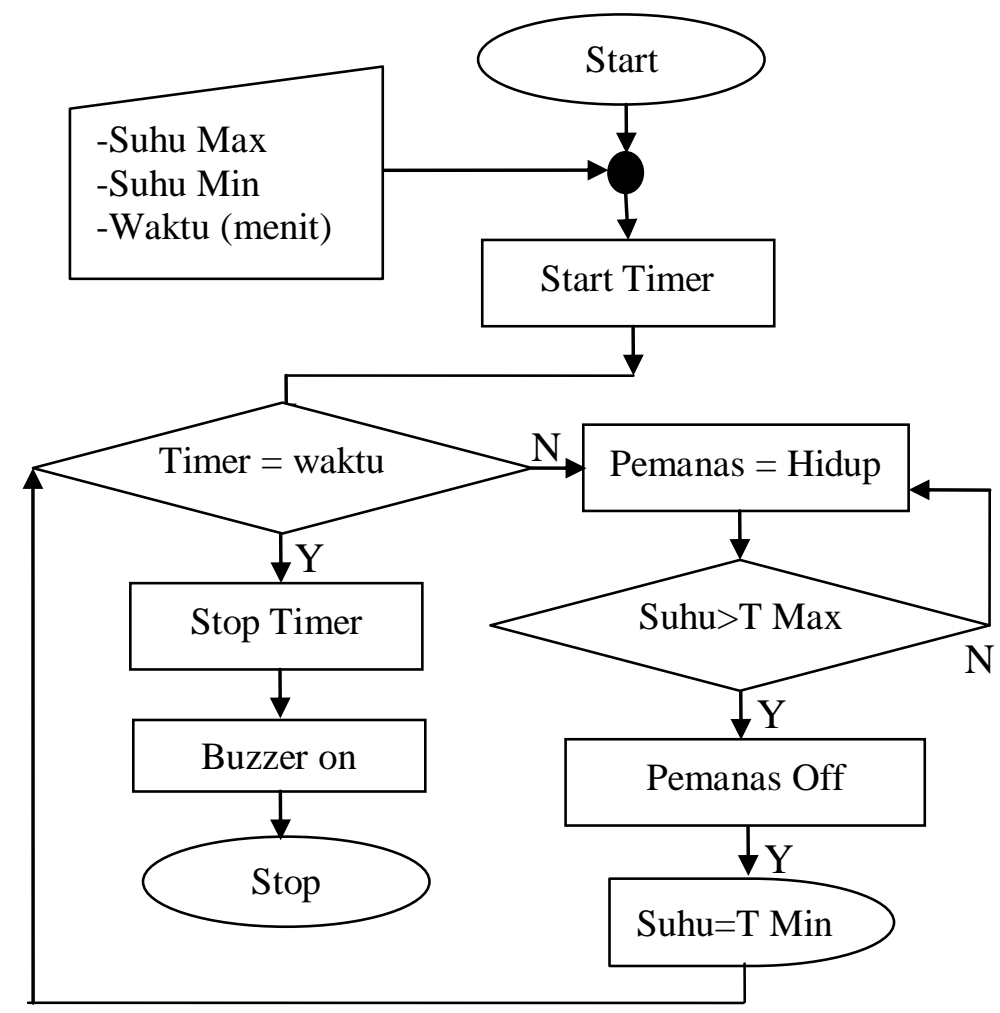

Gambar 6. Flowchart control incubaro dadiah display yang memperlihatkan temperature dan waktu secara real time. Alat ini memanfaatkan 2 buah relay untuk menghidupkan dan mematikan pemanas (heater) sertta buzzer.

Untuk sistem softwarenya sendiri, digunakan flowchart seperti yang terlihat pada gambar 7 . 


\section{Data dan Analisa Data}

Setelah sistem hardware dan software dari incubator dadiah diintegrasikan, maka akan terlihat seperti Gambar 8, adapun bentuk tampilan LCD ketika alat beroperasi diperlihatkan oleh Gambar 7. Untuk mengetahui apakah sistem control yang ada pada alat ini berfungsi dengan baik, maka dilakukan pengujian terhadap pewaktu beserta temperaturnya. Hasil pengujian dari kedua parameter tersebut terlihat pada Gambar 9 dan 10.

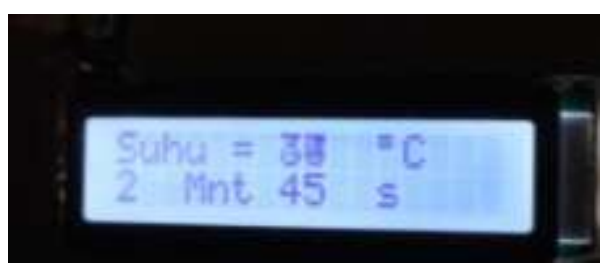

Gambar 7 : Penunjukan suhu LCD incubator

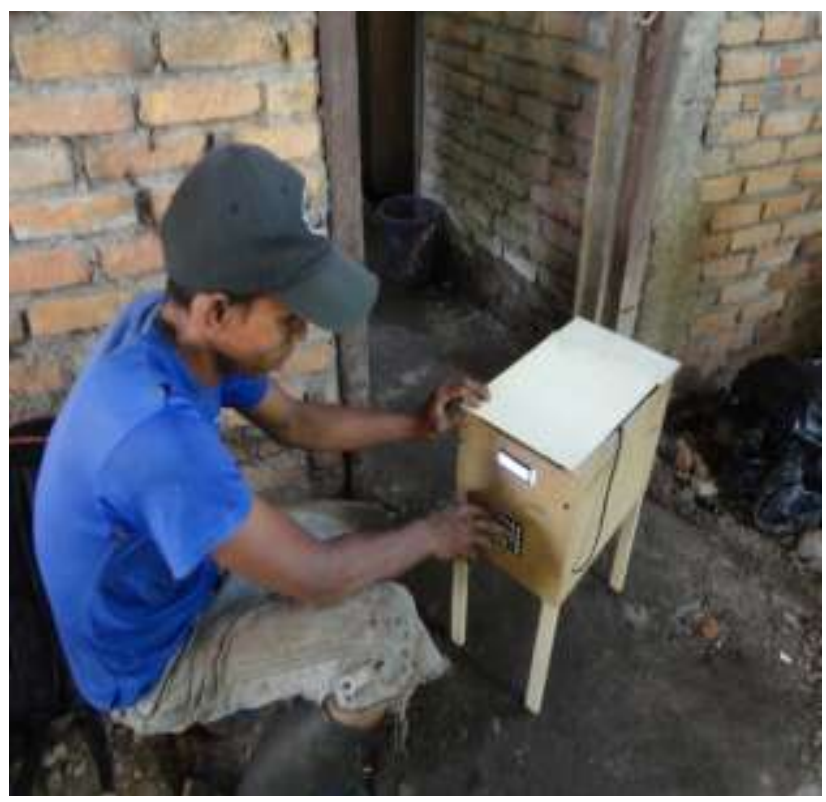

Gambar 8. Incubator yang sedang di operasikan

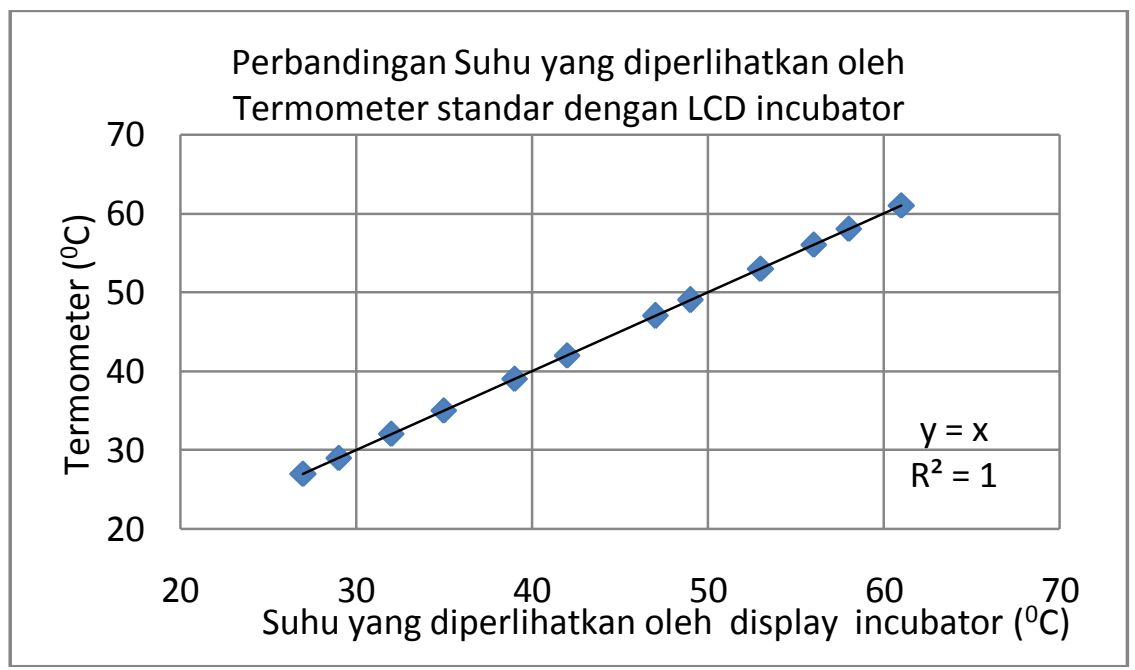

Gambar 9. Perbandingan antara suhu yang terukur oleh termometer digital dengan suhu yang diperlihatkan oleh display incubator

Dari Gambar 9 terlihat, temperature yang terukur oleh thermometer digital terlihat sama dengan apa yang ditampilkan oleh display incubator. Hal ini dibuktikan oleh besarnya koefisien determinasi dan persamaan yang ditampilkan bahwa nilai pada sumbu-x tepat sama dengan nilai yang ada pada sumbu-y. Nilai waktu yang terukur oleh stopwatch dengan waktu yang diperlihatkan oleh LCD incubator terlihat sama. Disamping dibuktikan oleh persamaan $\mathrm{y}=\mathrm{x}$. nilai koefisien determinasi dari persamaan itu adalah 1 


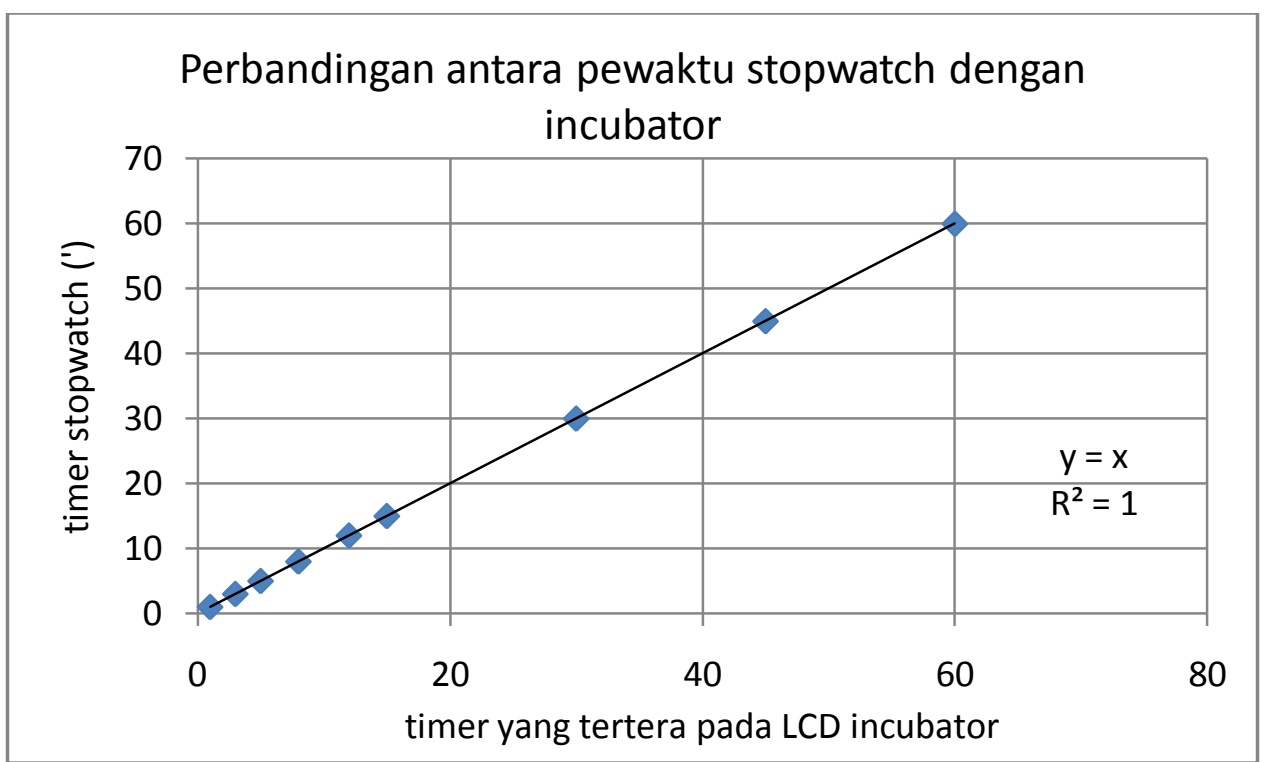

Gambar 10. Perbandingan antara waktu yang diukur dengan stopwatch dengan waktu yang ditampilkan oleh display incubator

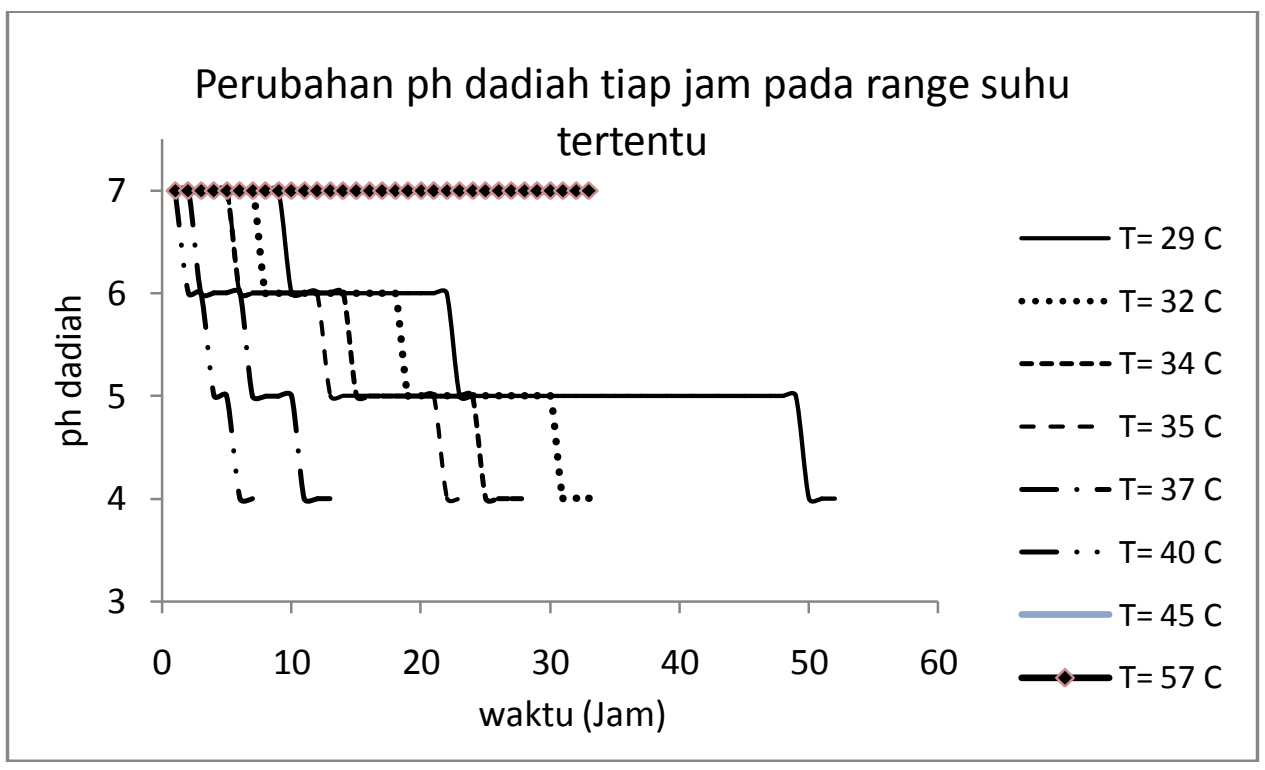

Gambar 11. Hasil pengujian pembuatan dadiah pada rentang suhu berbeda

Proses pembuatan dadiah dengan memanfaatkan incubator ini dilakukan pada range temperature yang berfariasi yaitu dari suhu $29{ }^{\circ} \mathrm{C}$ sampai $57{ }^{\circ} \mathrm{C}$. Hal ini bertujuan untuk mendapatkan nilai temperature optimal untuk menghasilkan dadiah dengan kualitas yang tetap terjaga. Dadiah dikatakan telah terbentuk jika ph-nya telah mencapai 4. Dari hasil pengujian yang telah dilakukan didapat suhu yang paling efektif untuk menghasilkan dadiah adalah pada suhu $40{ }^{\circ} \mathrm{C}$, sedangkan pada suhu $29{ }^{0} \mathrm{C}$ sampai $37{ }^{\circ} \mathrm{C}$ tetap dapat 
menghasilkan dadiah namun membutuhkan waktu yang lebih lama.

\section{KESIMPULAN}

Dari data dan analisa data yang dilakukan, ada beberapa hal yang dapat disimpulkan adalah; (1) control temperature dan pewaktu yang dibuat pada alat incubator dadiah dapat bekerja dengan baik dan sesuai dengan alat ukur standar; stopwatch untuk waktu dan thermometer digital untuk temperature. (2) sesuai dengan teori yang dijelaskan oleh Lee and Lucey, (2010) bahwa bakteri asam laktat berkembang dengan cepat pada suhu $40{ }^{0} \mathrm{C}$, ini terlihat dari proses pembuatan dadiah yang hanya butuh waktu 5 jam, dibandingkan dengan proses tradisional yang memerlukan waktu selama 50 jam.

\section{UCAPAN TERIMAKASIH}

Penelitian ini didanai oleh DIPA Politeknik Negeri Padang dengan nomor kontrak 134/PL9/PG/V/2012 serta dibantu oleh dua orang mahasiswa Jurusan Teknik Mesin angkatan 2009 yaitu Dani dan Chandra.

\section{PUSTAKA}

1. Lee, W. J., and Lucey, J. A. (2010). Formation and Physical Properties of Yogurt. Asian-Aust. J. Anim. Sci. Vol. 23, No. 9 : 1127 - 1136.

2. Sirait, CH. (1993). Pengolahan Susus Tradisional untuk Perkembangan Agroindustri Persusuan di Pedesaan. Laporan Penelitian Balai Peternakan Ciawi.

3. Sugitha, I. M., dan Afriyani. (2004). Potensi dadih untuk meningkatkan pendapatan masyarakat di Kabupaten Kerinci Propinsi Jambi. Jurnal Peternakan dan Lingkungan, Vol. 10 No. 1, 30-34.

4. Sunarlim, R. dan Setiyanto, H. (2001). Penggunaan berbagai tingkatkdar lemak susu kambing dan susu sapi terhadap mutu dan cita rasa yoghurt. Seminar Nasional Teknologi Peternakan dan Vetewriner 2001.

5. Yudoamijoyo, RM., T. Zoelfikar, S.R. Herastuti, A. Tomomatsu, A. (1983). Chemical dan microbiological aspect of dadih in Indonesia, Jpn J. Dairy and Food Sci, 32 (1) : 110 